\title{
Sengketa Lembaga Negara Antara Komisi Yudisial Dengan Mahkamah Agung
}

\author{
Riri Nazriyah
}

\section{Abstrak}

Constitutionally, the institution which has an authority to settle dispute between institutions is Constitutional Court. However, in the dispute between Judicial Commission and Supreme Court, the Constitutional Court is not able to handle the case. Because there is an exception of article 65 Constitutional Court.

\section{Pendahuluan}

Sebagai salah satu agenda reformasi nasional tahun 1998 adalah perubahan Undangundang Dasar Negara Republik Indonesia 1945, yang mengalami perubahan dalam satu rangkaian empat tahap, yaitu pada tahun $1999,2000,2001$, dan 2002. Salah satu hasil perubahan Undang-Undang Dasar 1945 adalah terbentuknya organ negara baru yang mendukung kerja lembaga peradilan, yakni Komisi Yudisial (Pasal 24B UUD Negara Republik Indonesia Tahun 1945).

Kehadiran beberapa komisi negara sebagai state auxialiary agency (lembaga negara tambahan), sebenarnya telah mempengaruhi gagasan trias politica yang memisahkan kekuasaan dalam tiga wilayah kekuasaan. Demikian juga bangunan sistem pemerintahan Indonesia setelah amandemen UUD 1945 yang menganut pemisahan kekuasaan dengan diikuti prinsip check and balances. Dengan munculnya beberapa komisi negara telah menimbulkan wacana bahwa, sistem pemerintahan Indonesia harus di tata ulang karena banyak terjadi tumpang tindih antara wewenang lembaga negara (dalam konteks tiga cabang kekuasaan yaitu eksekutif, legislatif, dan yudikatif) dengan komisi-komisi negara, misalnya kewenangan yang dimiliki oleh Komisi Yudisial (KY) dengan Mahkmah Agung (MA), demikian juga kewenangan yang dimiliki oleh Komisi Pemberantasan Korupsi (KPK) dengan Kejaksaan dan Kepolisian.

Kewenangan Komisi Yudisial telah dirumuskan dalam Pasal 24B UUD 1945 sebagai berikut: (1) Komisi Yudisial bersifat mandiri yang berwenang mengusulkan pengangkatan hakim agung dan mempunyai wewenang lain dalam rangka menjaga dan menegakkan kehormatan, keluhuran martabat, serta perilaku hakim; (2) Anggota Komisi Yudisial harus mempunyai pengetahuan dan pengalaman di bidang hukum serta memiliki integritas dan kepribadian yang tidak tercela; (3) Anggota Komisi Yudisial diangkat dan diberhentikan oleh Presiden dengan 
persetujuan DPR; (4) Susurian, kedudukan, dan keanggotaan Komisi Yudisial diatur dengan undang-undang.

Berdasarkan ketentuan Pasal 24B ayat (4) UUD 1945, dikeluarkaniah UU No. 22 Tahun 2004 tentang Komisi Yudisial. Pasal 20 UU tersebut menegaskan bahwa, dalam melaksanakan wewenangnya Komisi Yudisial mempunyai tugas melakukan pengawasan terhadap perilaku hakim dalam rangka menegakkan kehormatan dan keluhuran martabat serta menjaga perilaku hakim. Dalam rangka melaksanakan pengawasan untuk menegakkan kehormatan dan keluhuran martabat serta menjaga perilaku hakim, Komisi Yudisial bertugas menerima laporan masyarakat tentang perilaku hakim; meminta laporan secara berkala kepada badan peradilan berkaitan dengan perilaku hakim; melakukan pemeriksaan terhadap dugaan pelanggaran perilaku hakim; memanggil dan meminta keterangan dari hakim yang diduga melanggar kode etik perilaku hakim; dan membuat laporan hasil pemeriksaan yang berupa rekomendasi dan disampaikan kepada Mahkamah Agung dan/ atau Mahkamah Konstitusi, serta tindasannya disampaikan kepada Presiden dan DPR.

Namun, sampai saat ini belum ada ukuran yang jelas apa yang dimaksud kehormatan dan martabat hakim sehingga berpengaruh terhadap perilaku hakim. Di samping itu, mekanismelcara kerja atau aturan main yang harus dilakukan oleh Komisi Yudisial untuk memanggil dan memeriksa hakim yang diduga "bermasalah" belum dirumuskan secara konkrit, sehingga kewenangan pengawasan yang dimiliki Komisi Yudisial dianggap telah terjadi tumpang tindih dengan pengawasan internal yang dimiliki MA.Akhirnya muncul persengketaan kewenangan antara Komisi Yudisial dengan Mahkamah Agung.

Awal dan pokok persoalan yang memicu perseteruan kedua lembaga tersebut adalah perbedaan penafsiran yurisdiksi tugas pengawasan perilaku hakim. MA menganggap bahwa yang dimaksud pengawasan perilaku tidak termasuk pengawasan atas putusan hakim. Pengawasan terhadap putusan (teknis yudisial) adalah wewenang MA. Sebab, jika hal tersebut dilakukan oleh $\mathrm{KY}$ dapat mengancam independensi hakim. Permasalahan yang menarik untuk dikaji lebih lanjut, pertama, lembaga manakah yang lebih tepat melakukan pengawasan terhadap perilaku hakim, Komisi Yudisial ataukah Mahkamah Agung. Kedua, bagaimana menyelesaikan sengketa kewenangan antara Komisi Yudisial dengan Mahkamah Agung dalam pengawasan perilaku hakim.

\section{Kedudukan Komisi Yudisial}

Upaya untuk menjaga dan menegakkan kehormatan, keluhuran martabat, dan perilaku hakim diperlukan lembaga tersendiri yang bersifat mandiri agar pengawasan yang dilakukannya dapat efektif. Sistem pengawasan internal saja seperti adanya majelis kehormatan hakim, tidak terbukti efektif dalam melakukan pengawasan. Karena itu, dalam rangka perubahan UUD 1945, diadakan lembaga tersendiri yang bernama Komisi Yudisial.

Keberadaan lembaga baru yang akan mengawasi agar perilaku hakim menjadi simbol mengenai pentingnya infra struktur sistem etika perilaku dalam sistem ketatanegaraan Republik Indonesia menurut UUD 1945. Dengan adanya Komisi Yudisial ini sebagai salah satu lembaga negara yang 
bersifat menunjang (auxiliary organ) terhadap lembaga kekuasaan kehakiman, diharapkan bahwa infra struktur sistem etika perilaku di semua sektor dan lapisan supra struktur dan infra struktur bernegara Indonesia dapat ditumbuh-kembangkan sebagaimana mestinya dalam rangka mewujudkan gagasan negara hukum dan prinsip good govemance di semua bidang.

Ide tentang perlunya suatu komisi khusus untuk menjalankan fungsi-fungsi terientu yang berhubungan dengan kekuasaan kehakiman bukanlah hal yang baru. Dalam pembahasan RUU tentang Ketentuan-ketentuan Pokok Kekuasaan Kehakiman sekitar tahun 1968, sempat diusulkan pembentukan lembaga yang diberi nama Majelis Pertimbangan Penelitian Hakim (MPPH). Majelis ini berfungsi memberikan pertimbangan dan mengambil keputusan terakhir mengenai saran-saran atau usul-usul yang berkenaan dengan pengangkatan, promosi, kepindahan, pemberhentian, dan tindakan atau hukuman jabatan para hakim yang diajukan, baik oleh MA maupun Menteri Kehakiman.

Keberadaan komisi semacam ini sudah menjadi suatu trend di negara yang bercirikan demokrasi modern. Walaupun demikian, fungsi, organisasi, dan penamaannya berbeda antar satu negara dengan negara lainnya. Misalnya, di Afrika Selatan dikenal lembaga yang disebut Judicial Service Commission yang berfungsi memberikan rekomendasi dalam hal pemberhentian hakim, mengajukan calon Ketua Mahkamah Agung, dan memberikan masukan dalam hal pengangkatan Ketua serta Wakil ketua Mahkamah Konstitusi. Filipina memiliki lembaga sejenis dengan nama Judicial and Bar Council yang mempunyai fủngsi memberikan rekomendasi kepada Presiden dalam hal pengangkatan hakim dan komisi ombudsman serta menjalankan tugas-tugas lain yang ditetapkan oleh Mahkamah Agung. Di negara bagian New South Wales Australia, lembaga dengan nama Judicial Commission mempunyai fungsi untuk memberi bantuan kepada pengadilan-pengadilan untuk menjaga konsistensi putusan, mengkoordinir pelaksanaan pendidikan dan latihan bagi hakim, menerima dan memproses pengaduan/laporan tentang pejabat pengadilan, dan memberikan masukan hal-hal tertentu kepada Jaksa Agung.'

Ide tersebut muncul kembali dan menjadi wacana kuat sejak adanya desakan penyatuan atäp bagi hakim tahun 1998-an. Sebagaimana diketahui, pada tahun 1998 MPR mengeluarkan Ketetapan MPR RI No. XIMPR/1998 tentang Pokok-pokok Reformasi Pembangunan dalam Rangka Penyelamatan dan Normalisasi Kehidupan Nasional sebagai Haluan Negara. TAP MPR tersebut menyatakan perlunya segera diwujudkannya pemisahan yang tegas antara fungsi-fungsi yudikatif dan eksekutif.

Namun, ternyata masalahnya tidak sesederhana itu. Setelah adanya komitmen politik untuk memberlakukan penyatuan atap pemindahan kewenangan administrasi, personel, keuangan dan organisasi pengadilan dari departemen ke MA - muncul kekhawatiran baru di kalangan pemerhati hukum dan organisasi nonpemerintah yaitu kekhawatiran akan lahimya monopoli kekuasaan kehakiman oleh MA. Selain itu, ada kekhawatiran pula bahwa MA tidak akan mampu menjalankan tugas barunya itu dan hanya mengulangi

'Rifqi SjariefAssegaf, "Pengantar", dalam Wim Voemans, Komisi Yudisial di Beberapa Negara Uni Eropa, (Lembaga Kajian dan Advokasi untuk Independensi Peradilan-LeIP, Jakarta, 2002), him.v-ix 
kelemahan yang selama ini dilakukan oleh departemen. ${ }^{2}$

Untuk menghindari permasalahanpermasalahan di atas, kalangan pemerhati hukum dan organisasi nonpemerintah menganggap perlu dibentuk Komisi Yudisial. Komisi ini nantinya diharapkan dapat memainkan fungsi-fungsi tertentu dalam sistem yang baru, khususnya rekrutmen hakim agung dan pengawasan terhadap hakim.

Secara struktural kedudukan Komisi Yudisial dipösisikan sederajat dengan Mahkamah Agung dan Mahkamah Konstitusi. Namun demikian, perlu dicatat bahwa, meskipun secara struktural kedudukannya sederajat dengan Mahkamah Agung dan Mahkamah Konstitusi, tetapi secara fungsional, peranannya bersifat menunjang (auxiliary) terhadap 'lembaga kekuasaan kehakiman. ${ }^{3}$ Komisi Yudisial, meskipun fungsinya terkait dengan kèhakiman, tidak menjalankan fungsi kekuasaan kehakiman. Komisi Yudisial bukanlah lembaga penegak norma hukum (code of law), melainkan lembaga penegak kode etik (code of ethics). Lagi pula komisi ini hanya berurusan dengan persoalan kehormatan, keluhuran martabat, dan perilaku hakim, bukan dengan lembaga peradilan atau lembaga kekuasaan kehakiman secara institusional.

Keberadaannyapun sebenarnya berasal dari lingkungan internal hakim sendiri, yaitu dari konsepsi mengenai majelis kehormatan hakim yang terdapat di dalam dunia profesi kehakiman dan di lingkungan Mahkamah Agung. Artinya, sebelumnya fungsi ethical auditor ini bersifat internal. Namun, untuk lebih menjamin efektifitas kerjanya dalam rangka mengawasi perilaku hakim, maka fungsinya ditarik ke luar menjadi external auditor yang kedudukannya dibuat sederajat dengan pengawasannya.

Karena itu, meskipun secara struktural kedudukannya sederajat dengan Mahkamah Agung dan juga dengan Mahkamah Konstitusi, namun karena sifat fungsinya yang khusus dan penunjang (auxiliary), kedudukan protokolemya tidak perlu diperlakukan sama dengan Mahkamah Agung dan Mahkamah Konstitusi serta DPR, MPR, DPD, dan BPK. Karena, Komisi Yudisial itu sendiri bukanlah lembaga negara yang menjalankan fungsi kekuasaan negara secara langsung. Komisi Yudisial bukan lembaga yudikatif, eksekutif, apalagi legislatif. Komisi ini hanya berfungsi menunjang tegaknya kehormatan, keluhuran martabat, dan perilaku hakim sebagai pejabat penegak hukum dan lembaga yang menjalankan fungsi kekuasaan kehakiman (juriciary).

Dengan demikian, dalam menjalankan tugas dan kewenangannya, Komisi Yudisial juga bekerja berdampingan dengan Mahkamah Agung dan Mahkamah Konstitusi, bukan dengan pemerintah ataupun dengan lembaga perwakilan rakyat. Dalam melakukan pekerjaan Komisi Yudisial harus menjaga jarak dengan lembaga

\section{${ }^{2} \mathrm{lbid}$}

${ }^{3}$ Dari segi fungsinya, lembaga Negara ada yang bersifat utama atau primer, dan ada pula yang bersifat sekunder atau penunjang (auxiliany). Sedangkan dari segi hierarkinya dapat dibedakan ke dalam tiga lapis. Organ lapis pertama disebut sebagai lembaga tinggi Negara. Organ lapis kedua disebut sebagai lembaga Negara saja, sedangkan organ lapis ketiga merupakan lembaga daerah. Komisi Yudisial sebagai organ lapis kedua yang kewenangannya berasal dari UUD. Lihat Jimly asșhiddiqie, Perkembangan dan Konsolidasi Lembaga Negara Pasca Reformasi, Sekretariat Jenderal dan Kepaniteraan Mahkamah Konstitusi RI, Jakarta, 2006, hlm. 105-106. 
eksekutif dan parlemen agar tidak mudah mengontrol dan mengintervensi independensi kekuasaan kehakiman.

Sebaliknya, menurut ketentuan Pasal 2 UU No. 22 Tahun 2004 tentang Komisi Yudisial menegaskan: "Komisi Yudisial merupakan lembaga negara yang bersifat mandiri dan dalam pelaksanaan wewenangnya bebas dari campur tangan atau pengaruh kekuasaan lainnya". Artinya, Komisi Yudisial sendiri juga bersifat independen yang bebas dan hanus dibebaskan dari intervensi dan pengaruh cabang-cabang kekuasaan ataupun lembaga-lembaga negara lainnya.

Meskipun demikian, dengan sifat independen tersebut tidak berarti bahwa Komisi Yudisial tidak diharuskan bertanggung jawab oleh undang-undang. Dalam Pasal 38 UU No. 22 Tahun 2004 ditentukan bahwa:

(1) Komisi Yudisial bertanggung jawab kepada publik melalui Dewan Perwakilan Rakyat;

(2) Pertanggungjawaban kepada publik sebagaimana dimaksud pada ayat (1) dilaksanakan dengan cara:

a. Menerbitkan laporan tahunan; dan

b. Membuka akses informasi secara lengkap dan akurat.

(3) laporan sebagaimana dimaksud pada ayat (2) huruf a setidaknya memuat halhal sebagai berikut:

a. laporan penggunaan anggaran;

b. data yang berkaitan dengan fungsi pengawasan; dan

c. data yang berkaitan dengan fungsi rekruitmen Hakim Agung.

(4) Laporan sebagaimana dimaksud pada ayat (2) huruf a disampaikan pula kepada Presiden.
(5) Keuangan Komisi Yudisial diperiksa oleh Badan Pemeriksa Keuangan menurut ketentuan undang-undang.

\section{Tugas dan Wewenang Komisi Yudisial}

Pembentukan Komisi Yudisial di berbagai negara dilatar belakangi lima hal berikut ini: (a) lemahnya monitoring secara intensif terhadap kekuasaan kehakiman, karena monitoring hanya dilakukan secara internal saja; (b) tidak adanya lembaga yang menjadi penghubung antara kekuasaan pemerintah (executive power) - dalam hal ini Departemen Kehakiman - dan kekuasaan kehakiman (judicial power); (c) kekuasaan kèhakiman dianggap tidak mempunyai efisiensi dan efektivitas yang memadai dalam menjalankan tugasnya apabila masih disibukkan dengan persoalan-persoalan teknis non-hukum; (d) tidak adanya konsistensi putusan lembaga peradilan, karena setiap putusan kurang memperoleh penilaian dan pengawasan yang ketat dari sebuah lembaga khusus; (e) pola rekruitmen hakim selama ini dianggap terlalu bias dengan masalah politik, karena lembaga yang mengusulkan dan merekrutnya adalah lembaga-lembaga politik, yaitu Presiden atau parlemen. ${ }^{4}$

Kewenangan Komisi Yudisial telah dirumuskan sebagaimana tercantum dalam Pasal 24B UUD 1945 setelah perubahan sebagai berikut: (1) Komisi Yudisial bersifat mandiri yang berwenang mengusulkan pengangkatan hakim agung dan mempunyai wewenang lain dalam rangka menjaga dan menegakkan kehormatan, keluhuran martabat, serta perilaku hakim; (2) Anggota Komisi Yudisial

\footnotetext{
${ }^{4}$ A. Ahsin Thohari, Komisi Yudisial dan Reformasi Peradilan, (ELSAM, Jakarta, 2004), hlm. 152-154.
} 
harus. mempunyai pengetahuan dan pengalaman di bidang hukum serta memiliki integritas dan kepribadian yang tidak tercela; (3) Anggota Komisi Yudisial diangkat dan diberhentikan oleh Presiden dengan persetujuan DPR; (4) Susunan, kedudukan, dan keanggotaan Komisi Yudisial diatur dengan undang-undang. Dari keempat ketentuan tersebut, ada dua (2) hal yang berkaitan dengan tugas Komisi Yudisial, yaitu: mengusulkan pengangkatan hakim agung dan wewenang lain dalam rangka menjaga dan menegakkan keluhuran martabat, serta perilaku hakim.

Kewenangan tersebut dipertegas lagi dalam Undang-undang No 22 Tahun 2004 yang mengatakan bahwa dalam rangka melaksanakan wewenangnya mengusulkan pengangkatan Hakim Agung, Komisi Yudisial diberi tugas yaitu : melakukan pendaftaran calon Hakim Agung; melakukan seleksi terhadap calon Hakim Agung; menetapkan calon Hakim Agung; dan mengajukan calon Hakim Agung ke Dewan Perwakilan Rakyat (Pasal 14 UU No. 22 Tahun 2004). Wewenang Komisi Yudisial dalam mengusulkan pengangkatan hakim agung dimaksudkan untuk menghindari terjadinya politisasi perekrutan hakim agung. Secara alamiah, kekuasaan politik Presiden dan parlemen selalu ingin "mendudukkan" orangorangnya sebagai hakim agung. Komisi Yudisial diharapkan mampu meminimalisasi, kalau bukan mengeliminasi, terjadinya politisasi itu. ${ }^{5}$

Selanjutnya untuk melaksanakan peranannya menegakkan kehormatan dan keluhuran martabat serta menjaga perilaku hakim, Komisi Yudisial diberi tugas melakukan pengawasan terhadap perilaku hakim dalam rangka menegakkan kehormatan dan keluhuran martabat serta menjaga perilaku hakim (Pasal 20 UU No 22, 2004). Di samping itu, Komisi yudisial dalam menjalankan peranannya diberi tugas lain yaitu mengajukan usul penjatuhan sanksi terhadap hakim kepada pimpinan Mahkamah Agung dan/atau Mahkamah Konstitusi (Pasal 21 UU № 22, 2004).

Sebaliknya Komisi Yudisial di dalam menjalankan peranannya diberi kewenangan untuk dapat mengusulkan kepada Mahkamah Agung dan/atau Mahkamah Konstitusi untuk memberikan penghargaan kepada hakim atas prestasi dan jasanya dalam rangka menegakkan kehormatan dan keluhuran martabat serta menjaga perilaku hakim (Pasal 24 UU No 22 Tahun 2004).

Jadi untuk menegakkan kehormatan dan keluhuran martabat serta menjaga perilaku hakim Komisi Yudisial diberi beberapa kewenangan antara lain yaitu: pengawasan terhadap perilaku hakim; pengajuan usulan penjatuhan sanksi terhadap hakim; pengusulan penghargaan kepada hakim atas prestasi dan jasanya.

Dari beberapa peranannya tersebut di atas khususnya kewenangan untuk mengusulkan pengangkatan Hakim Agung diperkirakan sangat banyak berkaitan dengan proses seleksi di mana penyeleksian dilembagakan dalam suatu lembaga negara. Sudah barang tentu akan berdampak positif terhadap hasil kerja yang diinginkan. Anggota Komisi Yudisial dapat bekerja maksimal dan bersifat mandiri dalam rangka memilih Hakim Agung berkualitas, potensial, mengerti hukum dan profesional. Karena anggota Komisi Yudisial lebih mapan dan terjamin, sebab

${ }^{5}$ Kompas, 25 Juli 2005 
dibentuk berdasarkan undang-undang dasar dan pelaksanaan tugasnya dipayungi oleh suatu undang-undang.

Selanjutnya peranan Komisi Yudisial melakukan pengawasan perilaku hakim dapat dilakukan secara mandiri, karena tidak mempunyai hubungan administrasi, struktural, kolega maupun secara psikologis yang selama ini menjadi hambatan dalam melaksanakan pengawasan di dalam instansi atau lembaga sendiri. Hal ini tidak hanya dialami di Indonesia tetapi di negara-negara asing seperti Amerika dan Australia. Sebaliknya peranan menegakkan kehormatan dan keluhuran martabat serta menjaga perilaku hakim terlihat dari usul penjatuhan sanksi seperti teguran tertulis, pemberhentian sementara atau pemberhentian yang dilakukan oleh Komisi Yudisial bersifat mengikat (Pasal 23 (2) UU No 22, 2004). Selanjutnya usul penjatuhan sanksi tersebut diserahkan oleh Komisi Yudisial kepada Mahkamah Agung dan/atau Mahkamah Konstitusi. Namun, usulan tersebut masih dapat dianulir oleh ketentuan yang berbunyi bahwa hakim yang akan dijatuhi sanksi diberi kesempatan secukupnya untuk membela diri dihadapan Majelis Kehormatan Hakim (Pasal 23 (4) UU No 22, 2004). Disatu pihak apa yang direkomendasikan Komisi Yudisial belum ada kekuatan mengikat, hal ini terlihat dari diberinya kesempatan lagi kepada hakim yang diusulkan diberi sanksi untuk memberikan pembelaan secukupnya di depan Majelis Kehormatan Hakim. Di lain pihak usulan tersebut belum bersifat final. Timbul beberapa hal yang kurang jelas, apa yang dimaksud dengan Majelis Kehormatan Hakim, karena tidak dijelaskan dalam ketentuan umum Undang-undang No 22 tentang Komisi
Yudisial. Di samping itu, apabila pembelaan hakim yang diusulkan diberikan sanksi di depan Majelis Kehormatan Hakim diterima, bagaimana pula dampaknya terhadap usulan Komisi Yudisial? Jadi dapat disimpulkan bahwa rekomendasi Komisi Yudisial belum bersifat final dan belum mengikat. Selanjutnya usulan Komisi Yudisial untuk dapat mengikat dan bersifat final harus melalui tahapan pemeriksaan di depan Majelis Kehormatan Hakim dan Keputusan usul pemberhentian diajukan oleh Mahkamah Agung dan/atau Mahkamah Konstitusi kepada Presiden. Sedangkan sanksi teguran tertulis dan pemberhentian sementara dilakukan oleh siapa, ini yang belum jelas diatur oleh Undangundang Nomor 22 Tahun 2004.

Untuk melaksanakan peranannya mengawasi hakim, Komisi Yudisial dapat melakukan beberapa hal antara lain (Pasal 22 UU No.22 Tahun 2004): menerima laporan dari masyarakat tentang perilaku hakim; meminta laporan secara berkala kepada badan peradilan berkaitan dengan perilaku hakim; melakukan pemeriksaan dugaan pelanggaran perilaku hakim; memanggil dan meminta keterangan dari hakim yang diduga melanggar kode etik perilaku hakim; dan membuat hasil pemeriksaan yang berupa rekomendasi dan disampaikan kepada Mahkamah Agung dan/atau Mahkamah Konstitusi, serta tindasannya disampaikan kepada Presiden dan DPR.

Komisi Yudisial dalam melaksanakan perannya sebagai pengawas hakim tidak boleh sewenang-wenang. Komisi Yudisial wajib mentaati norma, hukum, dan ketentuan peraturan perundang-undangan, dan wajib menjaga kerahasiaan keterangan yang karena sifatnya merupakan rahasia Komisi Yudisial 
yang diperoleh berdasarkan kedudukannya sebagai anggota. Perlu diperhatikan bahwa pelaksaanaan tugas pengawasan tidak boleh mengurangi kebebasan hakim dalam memeriksa dan memutus perkara (Pasal 22 UU No.22 Tahun 2004).

\section{Sengketa Kewenangan Antarlembaga Negara}

Berdasarkan Perubahan Ketiga UUD 1945 Pasal 24 ayat (2), Mahkamah Konstitusi merupakan salah satu lembaga yang melakukan kekuasaan kehakiman. Kemudian pada Pasal 24C ayat (1) UUD 1945 ditegaskan bahwa "Mahkamah Konstitusi berwenang mengadili pada tingkat pertama dan terakhir yang putusannya bersifat final untuk menguji undang-undang terhadap Undang-Undang Dasar, memutus sengketa kewenangan lembaga negara yang kewenangannya diberikan oleh UUD, memutus pembubaran partai politik, dan memutus perselisihan tentang hasil pemilihan umum". Inilah dasar konstitusional kewenangan Mahkamah Konstitusi untuk memeriksa, mengadili, dan memutus sengketa kewenangan antarlembaga negara yang kewenangannya diberikan oleh UUD 1945.

Berdasarkan Pasal 2 Undang-Undang Nomor 24 Tahun 2003 tentang Mahkamah Konstitusi, "Mahkamah Konstitusi merupakan salah satu lembaga negara yang melakukan kekuasaan kehakiman yang merdeka untuk menyelenggarakan peradilan guna menegakkan hukum dan keadilan". Dilihat dari ketentuan ini, kewenangan Mahkamah Konstitusi untuk memutus sengketa kewenangan antarlembaga negara merupakan manifestasi dari pelaksanaan kekuasaan kehakiman yang dimiliki oleh Mahkamah Konstitusi tersebut.

Dalam sejarah ketatanegaraan Indonesia sebelum adanya Perubahan Ketiga UUD 1945 yang dilakukan pada tahun 2001, belumadaaturan mengenai mekanisme penyelesaian sengketa kewenangan antarlembaga negara. Lembaga yang memiliki kewenangan untuk memberi putusan terhadap sengketa kewenangan antariembaga negara tersebut juga belum ada. Karena itu, selama masa tersebut belum ada preseden dalam praktik ketatanegaraan Indoneisa mengenai penanganan sengketa kewenangan antar lembaga negara. Baru setelah adanya Perubahan Ketiga UUD 1945, yang mengadopsi pembentukan lembaga negara Mahkamah Konstitusi yang salah satu kewenangannya adalah memutus sengketa kewenangan antarlembaga negara yang kewenangannya diberikan oleh UUD 1945 , sistem ketatanegaraan Indonesia memiliki mekanisme penyelesaian jika terjadi sengketa kewenangan antarlembaga negara. ${ }^{6}$

Mengapa lembaga-lembaga negara itu bersengketa? Sebab dalam sistem ketatanegaraan yang diadopsikan dalam ketentuan UUD 1945 sesudah perubahan Pertama (1999), Kedua (2000), Ketiga (2000), dan Keempat (2002), mekanisme hubungan antarlembaga negara bersifat horizontal, tidak lagi bersifat vertikal. Jika sebelumnya kita mengenal adanya lembaga tinggi dan lembaga tertinggi Negara, maka sekarang tidak ada lagi

${ }^{6} \mathrm{Jimly}$ Asshiddiqie, Sengketa Kewenangan Antartembaga Negara, (Konstitusi Press, Jakarta, 2005), hlm. 2. Lihat juga Didit Hariadi Estiko dan Suhartono (Editor), Mahkamah Konstitusi Lembaga Negara Baru Pengawal Konstitusi, (Sekretariat Jenderal DPR-RI PusatPengkajjan dan Pelayanan Informasi (P3I), Jakarta, 2003), hlm. 123. 
lembaga tertinggi negara. MPR bukan lagi lembaga yang paling tinggi kedudukannya dalam bangunan struktur ketatanegaraan Indonesia, melainkan sederajat dengan lembagalembaga konstitusional lainnya, yaitu Presiden, DPR, DPD, MK, MA dan BPK?

Hubungan antara satu lembaga dengan lembaga yang lain diikat oleh prinsip checks and balances, di mana lembaga-lembaga tersebut diakui sederajat tetapi saling mengendalikan satu sama lain. Sebagai akibat adanya mekanisme hubungan yang sederajat itu, timbul kemungkinan dalam melaksanakan kewenangan masing-masing terdapat perselisihan dalam menafsirkan amanat UUD. Jika timbul persengketaan pendapat semacam itu, diperlukan organ tersendiri yang diserahi tugas untuk memutus final atas hal itu. Dalam sistem yang telah diadopsikan dalam UUD 1945 , mekanisme penyelesaian sengketa kewenangan demikian dilakukan melalui proses peradilan tata negara, yaitu melalui lembaga yang dibentuk tersendiri dengan nama Mahkamah Konstitusi. ${ }^{8} \mathrm{Di}$ samping alasan adanya perubahan struktur ketatanegaraan Indoensia pada saat ini yang kemudian perlu ada penyesuaian dalam mekanisme hubungan antarlembaga negara, kewenangan untuk memutus sengketa kewenangan antar lembaga negara memang diperlukan untuk mencegah agar sengketa tersebut tidak menjadi sengketa politik yang bersifat adversial. Sebab, jika sengketa politik yang justru terjadi, hal tersebut akan berdampak buruk terhadap mekanisme hubungan kelembagaan antarlembaga negara dan pelaksanaan fungsi dari lembaga negara yang bersengketa tersebut. Melalui kewenangan memutus sengketa kewenangan antarlembaga negara, Mahkamah Konstitusi pada dasarnya berperan menengahi dan meredakan sengketa itu dan memberikan solusi hukum.

Secara definitif, yang dimaksuơ dengan sengketa kewenangan antarlembaga negara yaitu perbedaan pendapat yang disertai persengketaan dan klaim antarlembaga negara yang satu dengan lembaga negara lainnya mengenai kewenangan yang dimiliki oleh masing-masing lembaga negara tersebut. ${ }^{9}$

Diadakannya mekanisme penyelesaian atas sengketa kewenangan konstitusional antarlembaga negara melalui Mahkamah Konstitusi menunjukkan bahwa penyusun Perubahan UUD 1945 mengandaikan bahwa dalam dinamika hubungan antarlembaga negara dapat timbul persengketaan pendapat mengenai kewenangan konstitusional masing-masing. Dalam paradigma pemikiran sebelumnya, tidak terbayangkan bahwa antarsesama lembaga negara dapat timbul sengketa kewenangan. Kalaupun timbul perselisihan antara satu lembaga dengan lembaga lain, maka perselisihan semacam itu diselesaikan begitu saja melalui prosesproses politik dan kultural, atau setiap masalah yang dihadapi diselesaikan secara politik oleh lembaga atau instansi atasan yang mempunyai kedudukan lebih tinggi dari lembaga yang terlibat persengketaan. Penyelesaian politis dan melalui mekanisme pengambilan keputusan yang bersifat vertikal itulah yang mewarnai corak penyelesaian masalah ketatanegaraan.

\footnotetext{
${ }^{7}$ Jimly Asshiddiqie, Ibid

${ }^{8} \mathrm{bid}$

9 Ibid., hlm. 4
} 


\section{Subjek dan Objek Sengketa}

Yang menjadi objek sengketa antar lembaga negara dalam rangka jurisdiksi Mahkamah Konstitusi adalah persengketaan (dispute) mengenai kewenangan konstitusional antarlembaga negara. Isu pokoknya bukan terletak pada kelembagaan lembaga negaranya, melainkan terletak pada soal kewenangan konstitusional yang dalam pelaksanaannya, apabila timbul sengketa penafsiran antara satu sama lain, maka yang berwenang memutuskan lembaga mana yang sebenarnya memiliki kewenangan yang dipersengketakan tersebut adalah Mahkamah Konstitusi.

Apakah yang dimaksud dengan lembaga negara, lembaga negara yang seperti apa yang dimaksudkan oleh Undang-Undang Nomor 24 Tahun 2003 dapat menjadi pemohon dalam perkara sengketa kewenangan yang kewenangannya diberikan oleh UUD 1945? Dengan bertitik tolak dari subjek lembaga negara biasanya membawa kita pada persoalan definisi lembaga negara yang cenderung diartikan menurut kerangka pemikiran lama tentang lembaga negara, yaitu lembaga negara dalam konteks tiga cabang tradisional alat perlengkapan negara, yaitu legislatif, eksekutif dan yudikatif sesuai doktrin trias politika Montesquieu. Padahal, sejak awal tahun 1945, UUD 1945 sama sekali tidak menganut ajaran trias politika ala Montesquieu tersebut.

Dalam pandangan Montesquieu, ketiga cabang kekuasaan itu terpisah secara tegas dan dijalankan oleh tiga organ pula secara pasti, di mana setiap organ hanya menjalankan satu fungsi yang tidak boleh tercampur satu sama lain. Dari pengertian demikian, timbul kesimpulan seolah-olah lembaga negara itu hanya ada tiga saja, yaitu lembaga yang menjalankan fungsi legislatif adalah parlemen, eksekutif adalah pemerintah, dan yudikatif adalah pengadilan.

Oleh karena itu, untuk mengetahui subjek lembaga negara yang mempunyai hak sebagai pemohon dapat mendekatinya dari objek kewenangan konstitusional yang dipersengketakan di antara lembaga negara yang bersangkutan. Yang menjadi pokok persoalan adalah kewenangan apakah yang diatur dan ditentukan dalam UUD yang dinisbatkan sebagai fungsi sesuatu organ yang disebut dalam UUD, dan apakah untuk melaksanakan kewenangannya itu terhambat atau terganggu karena adanya keputusan tertentu dari lembaga negara lainnya.

Apabila keduanya dapat dijawab dengan jelas, maka kemungkinan semacam ini memang dapat menjadi objek sengketa kewenangan konstitusional di Mahkamah

${ }^{10}$ Konsepsi tentang lembaga negara yang kewenangannya diberikan oleh undang-undang dasar, mengandung penafsiran yang beragam, yaitu: penafsiran luas, penafsiran moderat dan penafsiran sempit. Abdul Mukti Fadjar, Hukum Konstitusi dan Mahkamah Konstitusi, Cetakan Pertama, (Konstitusi Press, Jakarta, dan Citra Media, Yogyakarta, 2006), hlm. 184. Hal ini disebabkan pascaamandemen, konstitusi tidakmemberikan kejelasan konsepsi tentang lembaga Negara. Kenyataan ini berbeda dengan Ketetapan MPR RI No. IIIMPR 1978 tentang Kedudukan dan Hubungan Tata Kerja Lembaga Tertinggi Negara dengan/atau Antar Lembagalembaga Tinggi Negara, yang menyebutkan jenis dan kewenangan negara yang ada. UU No. 24 tentang Mahkamah Konstitusi juga tidakmemberikan kejelasan konsepsi tentang lembaga Negara. Lihat Fatkhurohman dkk, Memahami Keberadaan Mahkamah Konstitusi di Indonesia, (Citra aditya Bakti, Bandung ,2004), hlm. 35. 
Konstitusi. Yang penting dapat dibuktikan dengan jelas apakah lembaga negara pemohon memang memiliki kewenangan yang diberikan oleh UUD, dan apakah kewenangan konstitusional yang dimaksudkan itu memang ternyata dirugikan oleh keputusan tertentu dari lembaga negara termohon.

Pemohon perkara sengketa kewenangan konstitusional antar lembaga negara menurut ketentuan Pasal 61 ayat (1) UU No. 24 Tahun 2003 adalah lembaga negara yang kewenangannya diberikan UUD 1945 yang mempunyai kepentingan langsung terhadap kewenangan yang dipersengketakan. Ada 28 lembaga-lembaga negara yang secara eksplisit dan implisit disebut dalam UUD 1945 yaitu: (i) Presiden; (ii) Wakil Presiden; (iii) Dewan Pertimbangan Presiden; (iv) Kementerian Negara; (v) Duta; (vi) Konsul; (vii) Pemerintah Daerah Provinsi; (viii) Gubernur; (ix) DPRD Provinsi; $(x)$ Pemerintah Daerah Kabupaten; (xi) Bupati; (xii) DPRD Kabupaten; (xiii) Pemerintah Daerah Kota; (xiv) Walikota; (xv) DPRD Kota; (xvi) Majelis Permusyawaratan Rakyat; (xvii) Dewan Perwakilan Rakyat; (xviii) Dewan Perwakilan Daerah; (xix) Komisi pemilihan umum yang bersifat nasional, tetap dan mandiri, yang diatur lebih lanjut dengan undang-undang; $(x x)$ Bank Sentral yang susunan, kedudukan, kewenangan, tanggungjawab, dan independensinya diatur lebih lanjut dengan undang-undang; (xxi) Badan Pemeriksa Keuangan; (xxii) Mahkamah Agung; (xxiii) Mahkamah Konstitusi; (xxiv) Komisi Yudisial; (xxv) Tentara Nasional; (xxvi) Kepolisian Negara Republik Indonsia; (xxvii) Satuan pemerintahan daerah yang bersifat khusus atau istimewa; (xxviii) Kesatuan Masyarakat Hukum adat."

Di samping itu, Dalam Pasal 24 UUD 1945 ayat (3) ditentukan pula,"badan-badan lain yang fungsinya berkaitan dengan kekuasaan kehakiman diatur dalam undang-undang". Artinya, di samping ke-28 subjek kelembagaan tersebut di atas, ada pula badan-badan lain yang fungsinya berkaitan dengan kekuasaan kehakiman yang lebih lanjut diatur dalam undang-undang. Artinya, subjek hukum tata negara berdasarkan ketentuan UUD 1945, secara eksplisit dan implisit, berjumlah lebih dari 28 lembaga.

- Lembaga negara yang kewenangannya tidak dirumuskan secara ekplisit dalam UUD 1945 misalnya Komisi Pemilihan Umum dan Bank Sentral. Mengenai Bank Sentral, dalam Pasal 23D UUD 1945 ditegaskan bahwa, "Negara memiliki bank sentral yang susunan, kedudukan, kewenangan, tanggungjawab, dan independensinya diatur dengan undangundang." UUD 1945 sama sekali tidak menentukan apa saja kewenangan bank sentral itu, hal tersebut diatur oleh undang-undang. Jika kelak temyata, undang-undang mengatur hal-hal yang sebaliknya tidak menjamin independensi bank sentral, maka hal itu dikembalikan kepada Mahkamah Konstitusi untuk menilainya apabila dikemudian hari timbul sengketa berkenaan dengan independensi bank sentral itu dalam hubungannya dengan lembaga negara yang lain. ${ }^{12}$

"Jimly Asshiddiqie, Sengketa Kewenangan ...op. cit.,hlm. 17-29

12 Ibid 


\section{Sengketa Kewenangan Konstitusional}

Untuk melihat potensi sengketa antarlembaga negara dapat dilihat kepada kewenangan konstitusional yang diberikan oleh UUD dan peraturan perundang-undangan yang berlaku. Menurut Pasal 24B UUD 1945 setelah perubahan, kewenangan Komisi Yudisial (KY) dirumuskan sebagai berikut, Komisi Yudisial bersifat mandiri yang berwenang mengusulkan pengangkatan hakim agung dan mempunyai wewenang lain dalam rangka menjaga dan menegakkan kehormatan, keluhuran martabat, serta perilaku hakim. Untuk kewenangan yang pertama Komisi Yudisial akan bersinggungan dengan DPR sebagai lembaga yang memilih calon hakim agung, Presiden yang akan menetapkan hakim agung, dan MA. Untuk kewenangan kedua, Komisi Yudisial akan bersinggungan dengan MA dan MK sebagai lembaga yang akan menjadi objek pengawasan. Kewenangan kedua inilah yang sekarang telah menimbulkan sengketa antara $K Y$ dengan MA.

Keberadaan Komisi Yudisial teiah membuat para hakim di seluruh negeri ini, termasuk hakim agung merasa terusik karena kinerja $\mathrm{KY}$ dalam pengawasan dinilai telah menganggu kinerja mereka. Sejak anggota $K Y$ dilantik dan mulai bekerja pada Agustus 2005 lalu hubungan KY - MA belum pernah menunjukkan keharmonisan. Bahkan, yang terlihat sebaliknya. KY langsung dihadapkan pada pengaduan kasus penyimpangan sidang Pilkada Depok. Setelah melihat adanya kesalahan, rekomendasi sanksi bagi para hakim PT Jawa Barat yang menangani dilayangkan ke MA.

Awal dan pokok persoalan yang memicu perseteruan kedua lembaga tersebut sebenarnya adalah perbedaan penafsiran yurisdiksi tugas pengawasan perilaku hakim. MA menganggap bahwa yang dimaksud pengawasan perilaku tidak termasuk pengawasan atas putusan hakim (dan eksekusi putusan). Pengawasan terhadap putusan (teknis yudisial) adalah wewenang MA. Sebab, jika hal tersebut dilakukan oleh KY dapat mengancam independensi hakim. ${ }^{13}$

Dalam batas tertentu, alasan ini dapat dimengerti. Apalagi ada kekhawatiran lain bahwa nantinya bisa jadi KY ditempatkan selayaknya lembaga banding jika ada ketidakpuasan pencari keadilan atas suatu putusan. Pada gilirannya hal ini akan merusak sistem dan melahirkan ketidakpastian hukum. ${ }^{14}$

KY memandang bahwa sudah selayaknya pengawasan terhadap putusan masuk dalam wilayah kerja mereka. Pertimbangannya analog dengan apa yang selama ini sering diungkapkan hakim: "hanya dengan memegang berkas putusan seorang hakim senior dapat mengetahui apakah hakim 'main' dalam

${ }^{13}$ Dalam hal ini Jimly Asshiddiqie mengemukakan bahwa, $\mathrm{KY}$ tidak boleh memasuki ranah substansi putusan ataupun melakukan hal-hal lain yang dapat berakibat timbulnya ketakutan di kalangan para hakim dalam melaksanakan putusan. Hal ini dapatmempengaruhi sikap bebas atau kemerdekaan para hakim dalam memeriksa dan memutus perkara-perkara lain. Jika demikian yang terjadi, maka salah satu roh kekuasaan kehakiman telah dihancurkan, dan dengan demikian pilar negara hukum juga menjadi runtuh karenanya. Jimly Asshiddiqie, Perkembangan dan Konsolidasi ... Op. cit., hlm. 192-193.

${ }^{14}$ Rifqi S. Assegaf, Mahkamah Agung vs Komisi Yudisial, www. Hukumonline.com. Diakses tanggal 2 Januari 2006 


\section{memutus perkara". ${ }^{15}$}

Kewenangan Komisi Yudisial sebagaimana tercantum dalam Pasal 13 huruf (b) yaitu, menegakkan kehormatan dan keluhuran martabat serta menjaga perilaku hakim. Selanjutnya untuk melaksanakan wewenang sesuai dengan Pasal 13 huruf (b) tersebut, Komisi Yudisial diberi tugas melakukan pengawasan terhadap perilaku hakim dalam rangka menegakkan kehormatan dan keluhuran martabat serta menjaga perilaku hakim (Pasal 20 UU No 22, 2004).

Pasal 32 ayat (1) UU No. 14 Tahun 1985 tentang Mahkamah Agung menegaskan bahwa,"Mahkamah Agung melakukan pengawasan tertinggi terhadap penyelenggaraan peradilan di semua lingkungan peradilan dalam menjalankan kekuasaan kehakiman. Ayat (2) menyatakan bahwa, "Mahkamah Agung mengawasi tingkah laku dan perbuatan para hakim di semua lingkungan peradilan dalam menjalankan tugasnya.

Dengan kewenangan itu, masyarakat menaruh harapan besar kepada Komisi Yudisial untuk memperkuat dan menyelamatkan agenda reformasi di peradilan. Karena itu, lembaga yang lebih tepat melakukan pengawasan terhadap perilaku hakim, adalah Komisi Yudisial. Sebab, ini merupakan bentuk kesadaran bahwa pengawasan objektif terhadap kekuasaan kehakiman hanya dapat dilakukan dengan cara melibatkan unsur-unsur masyarakat seluas-luasnya, bukan hanya pengawasan secara intemal agar terhindar dari semangat korps, menipulasi, dan distorsi.

Hubungan KY dengan MA semakin renggang ketika Bagir Manan menolak memenuhi panggilan $K Y$ terkait dengan kasus Probosutedjo. Kemudian KY mengeluarkan gagasan seleksi ulang hakim agung dengan instrumen Peraturan Pemerintah Pengganti Undang-Undang (Perppu). Perseteruan semakin meruncing manakala beberapa media massa memberitakan bahwa 13 hakim agung dianggap bermasalah. Pemberitaan tersebut telah membuat kamarahan MA, dan melaporkan ketua KY ke Kepolisian dengan tuduhan pencemaran nama baik. Tensi perseteruan tersebut agak mengendur saat hakim agung Artidjo Alkostar melakukan perdamaian dengan Ketua KY Busyro Muqoddas.

Nampaknya, perdamaian Artidjo Alkostar dengan Busyro Muqoddas serta pembentukan tim fasilitator berkurang maknanya ketika $\mathbf{4 0}$ hakim agung mengajukan uji materiil terhadap UU No. 22 Tahun 2004 tentang Komisi Yudisial ke Mahkamah Konstitusi. Dijelaskan dalam surat permohonan bahwa, Pasal 1 angka 5, Pasal 20, Pasal 21, Pasal 22 ayat (1) huruf $e$ angka 5, Pasal 23 ayat (2,3 dan 5), Pasal 24 ayat (1) dan Pasal 25 ayat (3) UU KY bertentangan dengan Pasal 24B UUD 1945.

Dalam permohonan, terdapat dua alasan yang mendasari para hakim agung mengajukan judicial review. Pertama, tentang pengaturan hakim yang menurut mereka, kata "hakim" dalam Pasal 24B UUD 1945 bukanlah seluruh hakim.

${ }^{15}$ Dalam hal ini Laica Marzuki mengemukakan bahwa, KomisiYudisial dalam menjalankan kewenangannya tidak boleh mengurangi kebebasan dan kemandirian hakim. Namun, bukan tidak mungkin dari putusan hakim didapatkan adanya petunjuk bagi suatu perilaku hakim yang dipandang melanggar kode etik perilaku hakim. Keterlibatan KY selaku pengawas melalui koridor adanya perbuatan tercela dari hakim bukan memasukisubstansi putusan. Lihat Kompas, 8 Mei, 2006. 
Kedua, tentang kewenangan pengawasan $\mathrm{KY}$. Menurut mereka, secara universal kewenangan pengawasan $K Y$ tidak mencakup hakim agung pada MA. Karena, KY adalah mitra MA dalam melakukan pengawasan terhadap para hakim pada badan peradilan yang ada di bawah MA.

- Berdasarkan uraian di atas muncul pertanyaan, bagaimana menyelesaikan sengketa kewenangan antara Komisi Yudisial dengan Mahkamah Agung dalam pengawasan perilaku hakim. Apakah Mahkamah Konstitusi mempunyai wewenang untuk menyelesaikan sengketa antara $\mathrm{KY}$ dan MA.

Mahkamah Konstitusi (MK), adalah sebuah lembaga negara yang dibentuk setelah adanya Perubahan UUD 1945 mempunyai wewenang antara lain memutus sengketa kewenangan lembaga negara yang kewenangannya diberikan oleh UUD (Pasal 24C). Dengan dibentuknya MK, maka ada satu mekanisme penyeleșaian sengketa antarlembaga negara melalui instrumen pengadilan, yang diharapkan setiap sengketa dapat diselesaikan dengan sandaran hukum yang memadai. Kewenangan MK tersebut lebih diperjelas dalam UU No. 24 Tahun 2003 Pasal 61, yang menyatakan pemohon adalah lembaga negara yang kewenangannya diberikan oleh UUD Negara Republik Indonesia Tahun 1945 yang mempunyai kepentingan langsung terhadap kewenangan yang dipersengketakan. Kemudian dalam Pasal 63 ditegaskan, MK dapat mengeluarkan penetapan yang memerintahkan pada pemohon dan/atau termohon untuk menghentikan sementara pelaksanaan kewenangan yang dipersengketakan sampai ada putusan MK.
Berkaitan dengan sengketa yang dapat diajukan ke MK, UUD telah mengatur dan memberi batasan secara tegas yaitu, pertama, menyangkut sengketa kewenangan. Pokok sengketa yang dapat diajukan ke MK adalah sengketa kewenangan, bukan sengketa yang lain. Adapun sumber kewenangan yang disengketakan bisa saja diperoleh baik dari UUD maupun dari peraturan-peraturan lain. Kedua, yang bersengketa adalah lembaga negara dan lembaga negara yang dimaksud hanyalah lembaga negara yang kewenangannya diberikan oleh UUD. Dengan demikian, lembaga negara yang memperoleh kewenangan dari selain UUD tidak dapat mengajukan permohonan sengketa kewenangan antarlembaga negara di MK. ${ }^{16}$

Sengketa antara $K Y$ dengan MA sepatutnya diselesaikan secara hukum bukan melalui dialog perseorangan di dalam kedua lembaga tersebut, karena hal ini menyangkut persoalan kewenangan kelembagaan negara bukan konflik antara orang perseorangan, sehingga penyelesaian yang dilakukan juga harus berdasarkan kewenangan yang diberikan oleh undang-undang.

Akan tetapi kalau sengketa antara KY dengan MA dibawa ke MK, akan muncul persoalan baru, karena MA adalah satusatunya lembaga negara yang dikecualikan dari kemungkinan menjadi pihak dalam perkara sengketa kewenangan konstitusional sebagaimana ditentukan oleh Pasal 65 UU No. 24 Tahun 2003. Pasal ini menentukan, "Mahkamah Agung tidak dapat menjadi pihak dalam sengketa kewenangan lembaga Negara yang kewenangannya diberikan oleh

${ }^{16}$ Firmansyah Arifin dkk, Lembaga Negara dan Sengketa Kewenangan antar Lembaga Negara, (diterbitkan oleh Konsorsium Reformasi Hukum Nasional (KRHN) bekerjasama dengan Mahkamah Konstitusi Rl, Jakarta, Cetakan I, 2005), hlm. 123. 
Undang-Undang Dasar Negara Republik In்donesia Tahun 1945 pada Mahkamah Konstitusi." Ironis memang. MK dibentuk untuk menyelesaikan' sengketa kewenangan lembaga negara tetapi ternyata MK tidak dapat menyelesaikannya karena kendala yuridis yang diciptakan pihak legislator.

Tidak begitu jelas alasan mengapa MA dikecualikan dalam hal ini, kecuali bahwa dalam proses pembahasan rancangan undang-undang tentang MK berkembang pengertian bahwa MA merupakan lembaga kekuasaan kehakiman yang bersifat independen dan putusannya juga bersifat final dan mengikat. Jika terhadap putusan kasasi MA akan digugat kembali, maka satu-satunya mekanisme yang tersedia adalah melalui lembaga peninjauan kembali putusan. ${ }^{17}$

Tetapi, hal ini dipandang tidak logis karena, dengan sendirinya putusan MA bersifat final dan mengikat dan tidak dapat dimaksudkan dapat diuji lagi oleh lembaga lain, meskipun di beberapa negara lain justru sebaliknya putusan kasasi yang dinilai bertentangan dengan UUD dapat dibatalkan oleh MK. Dalam perkara sengketa kewenangan konstitusional, yang dipersoalkan bukanlah putusan MA yang terkait dengan perkara, melainkan hal-hal lain yang menyangkut pelaksanaan ketentuan UUD yang berhubungan dengan kewenangan MA sebagai lembaga negara yang kewenangannya diberikan oleh UUD.

Mahkamah Konstitusi mempunyai wewenang untuk memutus sengketa kewenangan. lembaga negara yang kewenangannya diberikan oleh UUD. Pengertian sengketa kewenangan konstitusional terdapat dua unsur yang harus dipenuhi, yaitu (i) adanya kewenangan konstitusional yang ditentukan. dalam UUD; dan (ii) timbuinya sengketa dalam pelaksanaan kewenangan konstitusional tersebut sebagai akibat perbedaan penafsiran di antara dua atau lebih lembaga negara yang terkait.

Seperti halnya sengketa yang terjadi antara $K Y$ dengan $M A$, adanya perbedaan penafsiran mengenai kata "hakim" dalam Pasal 24B UUD 1945. Menurut para hakim agung, kata hakim tidak bisa diartikan sebagai seluruh hakim. Karena menurut mereka, pengangkatan dan pemberhentian hakim seperti yang diatur dalam Pasal 25 UUD 1945 diatur dalam UU yang berbeda. Yakni, untuk hakim peradilan umum diatur dalam UU No. 8 Tahun 2004 tentang Peradilan Umum, hakim Peradilan Tata Usaha Negara diatur dalam UU No.Tahun 2004 tentang PTUN. Hakim Agama diatur dalam UU No. 7 Tahun 1989 tentang Peradilan Agama. Hakim Militer diatur dalam UU No. 31 Tahun 1997 tentang Peradilan Militer. Sementara, Hakim Agung diatur dalam UU No. 5 tahun 2004, Hakim Konstitusi diatur dalam UU No. 24 Tahun 2003. Karenanya, kewenangan KY menurut para hakim agung tidak menjangkau hakim MA dan MK. Alasannya, hakim agung dan hakim konstitusi ini tidak seluruhnya berasal dari hakim tingkat I maupun banding.

Sementara, mengenai pengawasan $\mathrm{KY}$, pasal-pasal yang mengatur perihal usul penjatuhan sanksi bagi hakim agung dan hakim konstitusi (Pasal 21, 23 ayat (2,3 dan 5), Pasal 24 ayat (1) dan Pasal 25 ayat ( 3 dan 4) UU No. 22 Tahun 3004 menurut mereka bertentangan dengan semangat Pasal 24, 24B dan C UUD 1945. Para hakim agung berpandangan pasal tersebut $(24,24 B$ dan C)

\footnotetext{
17Jimly Asshiddiqie, Op. cit. HIm. 23-24.
} 
memberi kewenangan kepada MA dan MK untuk membentuk majelis kehormatan hakim.

Menurut Busyro Muqoddas, ${ }^{18}$ hakim agung termasuk dalam lingkup pengawasan KY. Sesuai kamus hukum atau ensiklopedi, hakim adalah seseorang yang mempunyai jabatan publik berwenang untuk memeriksa, mengadili suatu perkara. Ini termasuk hakim agung dan itu ada dalam UU KY. Hakim bisa dibedakan menurut kekhususannya misalnya, hakim agama, hakim militer, atau hakim tata usaha negara. Selain itu, hakim bisa dibedakan menurut hierarkinya, yaitu hakim di pengadilan tingkat pertama, banding, atau kasasi. Semua itu adalah hakim dan bisa diawasi KY sesuai dalam UU KY. Sri Soemantri juga mengemukakan bahwa, yang dimaksud hakim dalam Pasal 24B UUD 1945 setelah perubahan termasuk hakim agung. ${ }^{19}$

Di samping itu, dalam naskah akademis rancangan undang-undang KY halaman 45 yang dibuat oleh MA pada 2003 dikatakan bahwa, salah satu dari lima tugas KY dalam fungsinya untuk menjaga dan menegakkan kehormatan, keluhuran martabat serta perilaku hakim adalah "pengawasan dan pendisiplinan hakim (termasuk hakim agung)". Dalam penjelasan footnote-nya, kata "menjaga" dalam - Pasal 24B UUD 1945 diwujudkan dalam tugas "pengawasan" sedangkan kata "menegakkan" diwujudkan dalam tugas "pendisiplinan" atau "menjatuhkan sanksi disiplin". Selain itu, pada halaman 58 disebutkan "redaksional yang digunakan Pasal 24B amandemen Ketiga UUD 1945 adalah '...perilaku hakim'. Kalimat hakim dalam naskah akademis harus diartikan sebagai seluruh hakim, baik hakim tingkat I, banding dan tingkat kasasi (hakim agung)." Masih pada halaman yang sama dijelaskan, tidak tepat apabila UUD 1945 ditafsirkan secara gramatikal. Demikian juga dalam cetak biru MK yang dibuat pada tahun 2004 dikatakan bahwa, Komisi Yudisial, secara yuridis memiliki kewenangan untuk mengawasi hakim, baik di lingkungan peradilan umum maupun Mahkamah Konstitusi" ${ }^{20}$

Apabila dikaji secara mendalam, konflik yang terjadi antara KY dengan MA disebabkan adanya perbedaan penafsiran terhadap bunyi Pasal 24B UUD 1945. Kemudian muncul pertanyaan, siapakah pihak yang berwenang melakukan penafsiran terhadap UUD 1945. Sebagaimana telah dijelaskan di atas, yang menjadi objek sengketa antar lembaga negara dalam rangka jurisdiksi Mahkamah Konstitusi adalah persengketaan (dispute) mengenai kewenangan konstitusional antar lembaga negara. Isu pokoknya bukan terletak pada kelembagaan lembaga negaranya, melainkan terletak pada soal kewenangan konstitusional yang dalam pelaksanaannya, apabila timbul sengketa penafsiran antara satu sama lain, maka yang berwenang memutuskan lembaga mana yang sebenarnya memiliki kewenangan yang dipersengketakan tersebut adalah Mahkamah Konstitusi. Di

\section{${ }^{18}$ Jawa Pos, 22 Maret 2006}

${ }^{19}$ Kompas, 29 April 2006

${ }^{20}$ www. Hukumonline. Com. Diakses tanggal 16 Maret 2006. Hal yang sama juga dikemukakan oleh Lukman Hakim Saefuddin anggota Komisi III DPR dalam Sidang MK hari Selasa tanggal 2 Mei 2006 yang mengatakan bahwa, MAmemandang fungsi $K Y$ dalam pengawasan dan pendisiplinan hakim dilakukan terhadap - para hakim termasuk hakim agung Lihat Kompas, 3 Mei 2006. 
samping itu, Mahkamah Konstitusi sebagai organ konstitusi, didesain untuk menjadi pengawal dan sekaligus penafsir terhadap UndangUndang Dasar melalui putusan-putusannya. Untuk itu, lembaga yang berwenang untuk menyelesaikan sengketa kewenangan antara Komisi Yudisial dengan Mahkamah Agung dalam pengawasan perilaku hakim adalah Mahkamah Konstitusi.

Mengenai pembatasan yang ditentukan menurut ketentuan Pasal 65 UU No. 24 Tahun 2003 tersebut di atas, sebenarnya agak berlebihan. Sudah seharusnya Mahkamah Agung tidak perlu dikecualikan sebagai pihak dalam sengketa kewenangan lembaga negara. Untuk itu, UU No. 24 Tahun 2003 tersebut harus di amandemen, sehingga mekanisme penyelesaian sengketa antara $\mathrm{KY}$ dengan MA dapat diselesaikan melalui jalur konstitusional.

\section{Simpulan}

Berdasarkan kajian di atas dapat disimpulkan bahwa, Komisi Yudisial adalah lembaga yang lebih tepat melakukan pengawasan terhadap perilaku hakim. Sebab, ini merupakan bentuk kesadaran bahwa pengawasan objektif terhadap kekuasaan kehakiman hanya dapat dilakukan dengan cara melibatkan unsur-unsur masyarakat seluas-luasnya, bukan hanya pengawasan secara internal agar terhindar dari semangat korps, manipulasi, dan distorsi. Secara konstitusional lembaga yang berwenang untuk menyelesaikan sengketa kewenangan antara lembaga negara adalah Mahkamah Konstitusi, akan tetapi dalam masalah sengketa kewenangan antara Komisi Yudisial dengan Mahkamah Agung, Mahkamah
Konstitusi tidak dapat menyidangkan kasus tersebut karena adanya pengecualian dalam Pasal 65 UU MK yang menegaskan bahwa Mahkamah Agung tidak dapat menjadi pihak dalam sengketa kewenangan lembaga negara yang kewenangannya diberikan oleh UndangUndang Dasar Negara Republik Indonesia Tahun 1945 pada Mahkamah Konstitusi.

\section{Daftar Pustaka}

Abdul Mukti Fadjar, 2006, Hukum Konstitusi dan Mahkamah Konstitusi, Cetakan Pertama, Konstitusi Press, Jakarta dan Citra Media, Yogyakarta.

A. Ahsin Thohari, 2004, Komisi Yudisial dan Reformasi Peradilan, ELSAM, Jakarta Didit Hariadi Estiko dan Suhartono (Editor), 2003 Mahkamah Konstitusi Lembaga Negara Baru Pengawal Konstitusi, Sekretariat Jenderal DPR-RI Pusat Pengkajian dan Pelayanan Informasi (P3I), Jakarta Fatkhurohman dkk, 2004, Memahami Keberadaan Mahkamah Konstitusi di Indonesia, (Citra aditya Bakti, Bandung) Firmansyah Arifin dkk, 2005, Lembaga Negara dan Sengketa Kewenangan antarLembaga Negara, diterbitkan oleh Konsorsium Reformasi Hukum Nasional (KRHN) bekerjasama dengan Mahkamah Konstitusi RI, Jakarta, Cetakan I

Jimly Asshiddiqie, 2006, Perkembangan dan Konsolidasi Lembaga Negara Pasca Reformasi, Sekretariat Jenderal dan Kepaniteraan Mahkamah Konstitusi RI, Jakarta

_- 2005, Sengketa Kewenangan Antarlembaga Negara Konstitusi Press, Jakarta

Wim Voermans, 2002, Komisi Yudisial di Beberapa Negara Uni Eropa, Lembaga 
Kajian dan Advokasi untuk Independensi. Jawa Pos, 22 Maret 2006

Peradilan-LelP, Jakarta Kompas, 29 April 2006

UU No. 22 Tahun 2004 tentang Komisi Yudisial Kompas, 3 Mei 2006

UU No. 14 Tahun 1985 tentang Mahkamah - Kompas, 8 Mei 2006

Agung

Kompas, 25 Juli 2005 www. Hukumonline.com. 